ACBAR, SWABAC and ANCB Delegation to Rabul

\title{
Report and Comment
}

1 The ACBAR steering committee with a member of SWABAC and a member of ANCB visited Kabul from Monday 1 June to Thursday 4 June. The following persons participated:

Dr Azam Gul Michael stone Terje skavdal Jon Bennett Eng.Hakim Gul Gillani Popal Randolph Martin Noor Ahmed Jon Rothenberg
Head of Delegation Vice-Chair, ACBAR Treasurer, ACBAR Executive Director, ACBAR steering committee, ACBAR steering committee, ACBAR steering committee, ACBAR ANCB

SWABAC

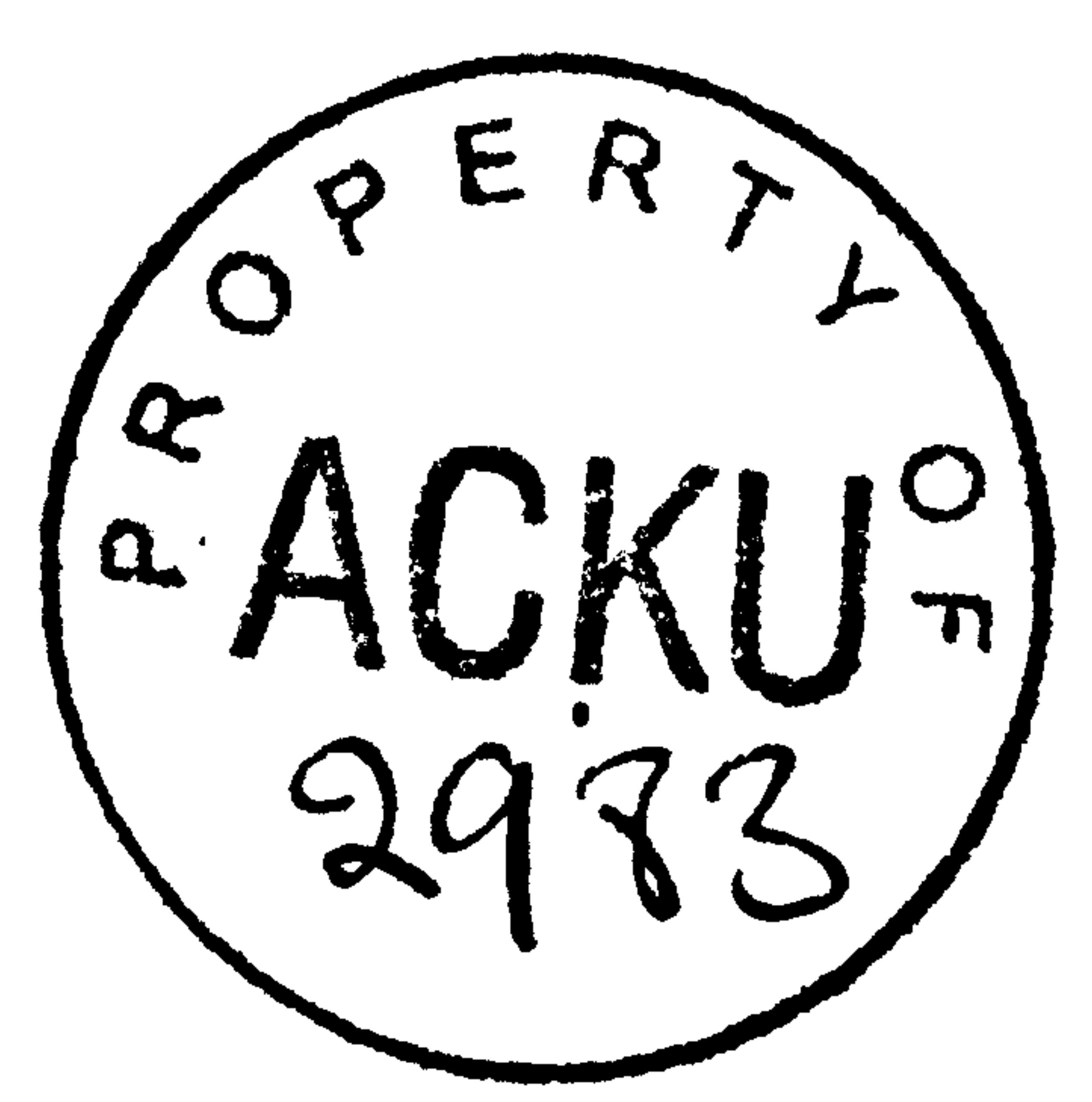

The delegation was later joined in Kabul by Bjorn Hagen (Director, SCA) and John Humphreys (Director, Afghanaid).

2 The delegation was received by David Lockwood and Francis Okelo of UNDP\UNOCA. We were provided with a gratis flight on Salam 01 and transport in Kabul. We would particularly like to thank Francis okelo for the assistance he gave to the delegation.

3 The purpose of the delegation was threefold: to provide the new government of Kabul with an overview of current NGO activities and capacities; to express the willingness of NGOs to continue their activities in Afghanistan; and to develop an appropriate Protocol Agreement for NGOs wishing to open an office in Kabul and begin working through the government.

\section{Ministry of Foreign Affairs}

1 Monday 1 June: Ministry of Foreign Affairs. The two Deputy Ministers, Dr Jalil Shams and Mr Hamid Karzai attended, along with three civil servants.

The delegation was warmly welcomed and assured that the importance of NGOs in Afghanistan was fully appreciated. Existing programmes would not be interfered with; indeed, all cross-border programmes should continue. However, the government must be informed of activities (probably through ACBAR) so that new assistance channelled through Kabul would not duplicate work already underway. 
We were informed that the Ministry of Foreign Affairs was the appropriate body through which to register foreign NGO and UN activities. A Protocol Agreement must first be signed prior to any formal activity undertaken by aid agencies. Individual ministries will deal with sectoral interests but the Ministry of Foreign Affairs is the primary authority.

We were informed that certain organisations had already attempted to undermine this authority. Under current circumstances, it was not possible to prevent individual organisations setting up arrangements with other ministries or local authorities but this was illegal and would be dealt with once the government was well established.

4 We assured the Ministry of our compliance with this requirement. We also offered to assist them in drawing up a suitable Protocol Agreement to be issued to all NGOs in a standard format. This would be submitted before the delegation left Kabul.

Afghan NGOs would very probably be dealt with by the Ministry of Social Affairs since their registration will be different. Some aspects of their operations - e.g. importation of foreign goods and the employment of foreign nationals - will have to be done through the Ministry of Foreign Affairs.

Subsequent meetings with various ministries were arranged through the Ministry of Foreign Affairs.

\section{Ministry of Education}

1 Tuesday 2 June: Ministry of Education. Mr Abdul Qayum, the Acting Minister, and one civil servant received the delegation.

2 The Ministry was aware of the enormous damage sustained by the education system over previous years. Educational establishments were run down, teachers poorly paid and degrees were almost worthless. They have begun burning communist books and replacing them with textbooks brought from Peshawar. An Islamic curriculum will be established soon.

All NGOs are welcome but must adhere to the requirements of the Ministry with respect to curriculum and standards. No organisation will be allowed to open schools, as before, outside of Ministry jurisdiction; all schools must be incorporated into a national structure. However, the Minister appreciated all efforts of NGOs in the past and assured us of their continuing cooperation and advice.

4 The primary authority of the Ministry of Foreign Affairs was recognised with respect to international NGO registration. 

WHO will send a high level delegation on 14 June and soon will begin implementing this plan. Ten priority projects have already been submitted. Accompanying the mission will be EMRO (Eastern Mediterranean Regional office of WHO) who will implement the EPI component. Dr Fatimie declared that he had no idea what UNICEF is doing since they had not visited the government either in Peshawar or Kabul.

6 A priority is to set up 6 regional offices. The government will appoint a Regional Director General of MOPH who will coordinate with shuras in Jalalabad, Qandarhar, Kabul, Kunduz, Balkh and Herat.

7 The ob\Gyn facility in Peshawar will be shifted to Jelalabad under the Medical College of Jelalabad; it will not be a private hospital.

8 NGOs were urged to follow the salary guidelines presented by the ACBAR consultant who has already had meetings with MOPH.

9 Entry ports have been instructed not to allow private importation of medicines, especially if they are untaxed. The government is worried about importation of out-of-date drugs and the use of inappropriate or dangerous drugs on the open market. NGO importations are exempt from tax.

10 The primary authority of the Ministry of Foreign Affairs was recognised with respect to registration of international NGOs.

\section{Ministry of Returnees}

1 Wednesday 3 June: Rehmatullah Wahidyar, the Acting Minister for Returnees, and three civil servants received the delegation.

2 Up to March 1993 the Ministry expects the return of as many as 2 million refugees from Pakistan and Iran. About 1,000 experts from Europe and America are also expected to return.

3 The government will be setting up 13 "guest houses" (camps) for returnees, of which 5 are already established. About 36,000 people can be accommodated at these camps at any one time. Mobile health clinics will also be established. NGOs are asked to contribute resources to these centres; more particularly, NGOs are asked to provide assistance in the villages when people return. 
4 The Minister claimed that the repatriation programme of UNHCR and the Pakistan government is not sufficient for the enormous numbers currently returning. NGOs should coordinate their activities through his Ministry, not through UNHCR. An office will be set up in Peshawar. He stressed that, contrary to UNHCR policy in Pakistan, the government will treat all returnees, registered or not, equally - i.e. assistance packages. should be given to all.

5 The primary authority of the Ministry of Foreign Affairs was recognised with respect to registration of international NGOs.

\section{Ministry of Construction}

1 Wednesday 3 June: Mohammed Yasser, the Acting Minister of Construction, received the delegation.

2 Although the authority of the Ministry of Foreign Affairs was recognised, the Ministry of Construction already have a written procedure for registration of NGOs. Several Arab NGOs have already availed themselves of this procedure.

3 The previous Minister is now an advisor and all civil servants and engineers have been kept on salary. Machinery and personnel are available to any NGO wishing to work through the Ministry.

4 Various specialists who laid mines for the old regime are now under the authority of this Ministry and will be available to de-mining agencies if required.

5 The Ministry has a provisional countrywide plan but must first work on priorities such as major roads, bridges and housing. NGOs are encouraged to begin work immediately on these sectors.

\section{Ministry of Foreign Affairs (second meeting)}

1 Thursday 4 June: the delegation was received by Hamid Karzai and two civil servants.

2 Mr Karzai thanked the delegation for the draft of a protocol for NGOs. He agreed that his officers would draft the final copy, including a few points specific to government requirements and give it to ACBAR within the next month. He reiterated the fact that this protocol must first be agreed by the Leadership Council. He also stressed that the final copies would be in the national language and in English. 
The delegation was unable, for security reasons, to see the Ministry of Social Affairs on behalf of Afghan NGos. The specific requirements for Afghan NGOs will be pursued at a later date by an ACBAR/NGO follow-up trip. However, the Deputy Minister was confident that Afghan NGOs would receive a full welcome in the future.

The Deputy Minister strongly emphasised that although in principle NGOs were welcome to begin work immediately, he could not recommend that they open offices in Kabul at this time. The security of personnel and property cannot be guaranteed. NGOs should continue as before in the provinces but wait for some time before entering Kabul.

\section{Meetings with UN bodies}

David Lockwood, Resident Representative for UNDP/UNOCA, arranged for the delegation to meet all heads of the UN in Kabul. He expressed his willingness to work very closely with NGos in preparing the UNDP Rehabilitation Strategy; an NGO representative is invited to sit on the panel preparing this strategy in the coming two months. Mr Lockwood accompanied the delegation to the first meeting with the Ministry of Foreign Affairs and strongly emphasised the role of NGOs in the reconstruction of Afghanistan.

\section{security}

The security situation in Kabul was poor during the week of the visit. UN vehicles had been stolen in broad daylight and the ICRC hospital had been the scene of open fighting between two party factions. Many shops were closed; an official $8.30 \mathrm{pm}$ curfew was in fact in place by $5.30 \mathrm{pm}$ because few people risked driving after this time. Some ministries were inaccessible (the Minister of Agriculture is still prevented from entering his Ministry); the University was closed; the Inter-Continental Hotel was occupied mostly by mujahidin. The city was full of heavily armed men on almost every street corner, including tanks, armoured personnel
carriers, etc.

The consensus from the delegates, the UN and, at our departure, the Ministry of Foreign Affairs, was that NGOs should not be considering opening offices until some stability in Kabul could be guaranteed. This should not affect ongoing programmes cross-border or in provincial capitals. 


\section{Future Action}

The draft of a standard NGO Protocol Agreement, written by the delegation, was left with the Ministry of Foreign Affairs. They will write the final draft and present it to ACBAR within the next two weeks, if possible. It must first be approved by the Leadership Council.

Jon Bennett will return to Kabul before the end of June to receive the final draft of this Protocol. NGOs in Pakistan will then be able to approach the Ministry of Foreign Affairs for signature and with a "covering letter" applicable specifically to their own NGO.

The general impression, in spite of security problems, was that the government has a very positive attitude towards NGOs and will do their utmost to encourage NGO operations in Afghanistan in the future. The role of NGOs in the past was fully appreciated - and, indeed, applauded - by almost all persons visited on this mission.

We would like to stress that this delegation's intention had not been to agree restrictions on behalf of NGOs before they have had an opportunity to comment: rather, we intended to assist the government in drafting a general protocol - similar to that held by most international governments - which could be acceptable to all parties and which would prevent the burden of having to draw up individual agreements with each NGO. Additions or subtractions may be discussed with the Ministry of Foreign Affairs.

Jon Bennett

pp. ACBAR steering Committee

9 June 1992

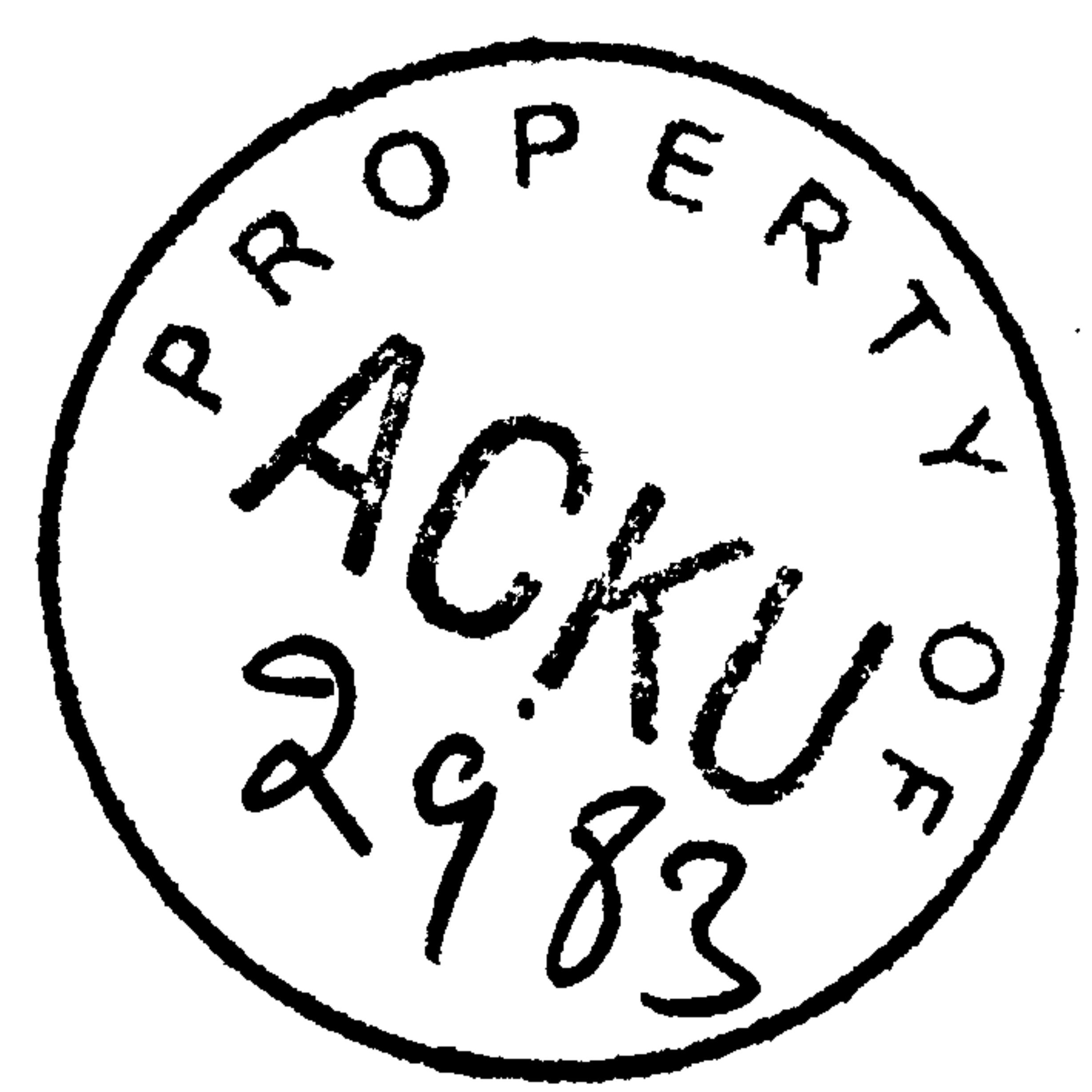

